\title{
Thermal Degradation and Damping Characteristic of UV Irradiated Biopolymer
}

\author{
Anika Zafiah M. Rus and Nik Normunira Mat Hassan \\ Sustainable Polymer Engineering, Advanced Manufacturing and Material Center (AMMC), \\ Universiti Tun Hussein Onn Malaysia, Parit Raja, Batu Pahat, 86400 Johor, Malaysia
}

Correspondence should be addressed to Anika Zafiah M. Rus; zafiah@uthm.edu.my

Received 5 April 2015; Revised 24 June 2015; Accepted 29 June 2015

Academic Editor: Dilip Depan

Copyright ( 2015 A. Z. M. Rus and N. N. M. Hassan. This is an open access article distributed under the Creative Commons Attribution License, which permits unrestricted use, distribution, and reproduction in any medium, provided the original work is properly cited.

\begin{abstract}
Biopolymer made from renewable material is one of the most important groups of polymer because of its versatility in application. In this study, biopolymers based on waste vegetable oil were synthesized and cross-link with commercial polymethane polyphenyl isocyanate (known as BF). The BF was compressed by using hot compression moulding technique at $90^{\circ} \mathrm{C}$ based on the evaporation of volatile matter, known as compress biopolymer $(\mathrm{CB})$. Treatment with titanium dioxide $\left(\mathrm{TiO}_{2}\right)$ was found to affect the physical property of compressed biopolymer composite (CBC). The characterization of thermal degradation, activation energy, morphology structure, density, vibration, and damping of CB were determined after UV irradiation exposure. This is to evaluate the photo- and thermal stability of the treated $\mathrm{CB}$ or CBC. The vibration and damping characteristic of CBC samples is significantly increased with the increasing of UV irradiation time, lowest thickness, and percentages of $\mathrm{TiO}_{2}$ loading at the frequency range of $15-25 \mathrm{~Hz}$ due to the potential of the sample to dissipate energy during the oscillation harmonic system. The damping property of $\mathrm{CBC}$ was improved markedly upon prolonged exposure to UV irradiation.
\end{abstract}

\section{Introduction}

Waste vegetable based palm oils are the most abundant biological sources and important raw materials for the production of biobased polyurethanes. The main components existing in waste vegetable oil are triglycerides with saturated and unsaturated fatty acids useful in many synthesis transformations and they become new polyol sources [1]. In polymer industry, waste vegetable oils which represent a major potential source of chemicals have been utilized as an alternative feedstock for biomonomers [2-4].

Synthesis of biomonomer is started with the preparation of catalyst to generate the epoxides from the unsaturated fatty compounds of the waste vegetable oil. The condensation process comprises acid-catalysed ring opening of the epoxides to form polyols. The polyol will be reacted with the crosslinking agents to produce flexible biopolymer foam and will be added to $\mathrm{TiO}_{2}$ filler to produce biopolymer composite foam.
Polyurethane (PU) foams are versatile engineering materials with a wide range of applications because of their properties that can be readily tailored to form different types of polymer composition. Generally, PU foams are one of the major productions of urethane polymer structure [5]. The formation of biopolymer foam followed the same general reaction of isocyanate with biomonomer and both of which are derived when polymerization reactions occur similar to nearly all polymeric materials [6]. The forming process of biopolymer foam consists of three basic stages such as bubble initiation, bubble growth, and cell opening [7].

In order to enhance the photostability of biopolymer foam, the pretreatment of the physical property of biopolymer foam is needed, which includes UV stabilizer filler such as titanium dioxide $\left(\mathrm{TiO}_{2}\right) . \mathrm{TiO}_{2}$ is also an inorganic pigment and is used as an additive of excellent UV screener to reflect the light away from the polymer surface [8]. This pigment is important in polymer as an inner screen for photoproducts and it limited the photooxidative phenomena. It can 
also be used to reduce cost, reinforcement, and hardening, improving slip and storage stability. Furthermore, $\mathrm{TiO}_{2}$ has been recognized as the most important photocatalyst for the degradation of many organic pollutants in water and air [9].

The development of foam block system of single degree of freedom is to measure the dynamic response of foam at different levels of compression and excitation. This is to identify the foam viscoelastic properties through a foam modeling that is designed. This concept is to design the foam block system which will contribute to seat-occupant system. The system can be applied in a wide range of polymeric materials for foam dynamic response measurement and its characterization based on the vibration of potential energy, kinetic energy, and energy loss (damping) [10, 11].

The performance of vibration transmissibility and damping characteristic of biopolymer foam using foam block system for automotive applications is important due to the method of transmissibility test that can be used in a wide range of polymeric materials which possess nonlinear viscoelastic properties. Vibration transmissibility is a ratio of the force amplitude transmitted to the amplitude foundation of the applying excitation. This method is also used to determine the damping characteristic of the system that consists of coulomb and viscous damping from free vibration decrements of mass spring system [12].

\section{Experimental}

2.1. Materials. The biomonomer conversions from waste vegetable oils are started with the in-house catalyst preparation to generate the epoxies from the unsaturated fatty compound. The acid-catalyst ring opening of the epoxides is to form polyols [13-17].

2.2. Preparation of Samples. The weights of compositions were determined based on the ratio of biomonomer and isocyanate with the ratio of $2: 1$ [16]. The biopolymer flexible (BF) foam was doped with titanium dioxide $\left(\mathrm{TiO}_{2}\right)$ Degussa at different percentages which is $0 \%, 2.5 \%, 5.0 \%, 7.5 \%$, and $10.0 \%$, equivalent to the weight of biomonomer. The mixture was vigorously stirred with hand mixer in a cup for 30 seconds. The mixtures were then immediately cast into an open mould to allow the biopolymer to expand out as foam. It was left for 6 hours to cure and was removed from the mould.

One hundred and sixty grams of biopolymer foam was weighed and filled in the mould cavity with internal core size of $180 \times 180 \times 15 \mathrm{~mm}$ in order to decrease the thickness and pore size by using hot compression moulding. The parameter of the hot compression machine was set at $90^{\circ} \mathrm{C}$ of temperature, under 26 tonnes of pressure within 1 hour [1822]. The compress biopolymer (CB) samples and compress biopolymer composite (CBC) were further prepared into $50 \mathrm{~mm} \times 50 \mathrm{~mm} \times 10 \mathrm{~mm}$ block. $\mathrm{CB}$ and CBC blocks were irradiated to UV light in UV Lamp Test Chamber Model HD703 (Haida International Equipment Co., Ltd.) at 250 hours, 500 hours, 750 hours, and 1000 hours at $50^{\circ} \mathrm{C}$ to simulate harsh environmental weather condition. This was carried out using an array of UV fluorescent lamps emitting light in the region from 280 to $320 \mathrm{~nm}$ with a tail extending to $400 \mathrm{~nm}$.

\subsection{Physical Characterization}

2.3.1. Thermal Gravimetric Analysis (TGA). Thermal gravimetric analysis (TGA) measurement of $\mathrm{BF}$ and $\mathrm{BC}$ was performed using Linseis TGA to characterize the thermal properties of samples according to ISO 11358. The weight loss and derivative weight loss were measured at $20^{\circ} \mathrm{C}$ to $900^{\circ} \mathrm{C}$ with heating rate of $10^{\circ} \mathrm{C} / \mathrm{min}$ under oxygen atmosphere and flow rate of $0.3 \mu \mathrm{L}$ using alumina crucible. Furthermore, activation energy of $\mathrm{BF}$ and $\mathrm{BC}$ samples was determined by using Flynn method [23].

2.3.2. Density. The CBC samples were cut into $10 \mathrm{~mm} \times$ $10 \mathrm{~mm} \times 5 \mathrm{~mm}$ to conduct the density test according to ASTM D3575 [20-24] at various UV irradiation exposure times calculated as follows:

$$
\text { Density, } \rho=\frac{m}{v} \text {, }
$$

where $m=$ mass of sample and $v=$ volume of sample.

2.3.3. Morphology Structure. The morphology surface structure of each BF and $\mathrm{CB}$ sample was sputter coated with gold at $25 \mathrm{~mA}$ plasma current and $2 \mathrm{~Pa}$ of chamber pressure to make them conducting. Cellular structure images were examined by using scanning electron microscope (SEM) of JEOL-JSM6380LA operating at $15 \mathrm{kV}$ at 30x magnification.

\subsection{Mechanical Characterization}

2.4.1. Vibration and Damping Measurement System. The vibration transmissibility test was developed to determine the effectiveness of $\mathrm{CBC}$ block to reduce the unwanted base vibration. The transmissibility test was generated at various base excitation levels, namely, $1 \mathrm{~mm}$ and $1.5 \mathrm{~mm}$ displacement and $0.1 \mathrm{G}$ (Gravity) and $0.15 \mathrm{G}$ (gravity) of the acceleration base excitation in frequency range of $2-30 \mathrm{~Hz}$ for $10 \mathrm{~mm}, 15 \mathrm{~mm}$, and $20 \mathrm{~mm}$ of samples thickness. Damping characterization of CBC block is studied by modeling a mass spring damper system at low frequency following ASTM D3580-95 [18-22].

\section{Result and Discussions}

3.1. Physical Characterization. The predetermined UV irradiation temperatures were based on weight loss curves (TG) and derivative thermogravimetric (DTG) evaluation of $\mathrm{BF}$ and $\mathrm{CB}$ samples. The first peak appeared at the temperature range less than $100^{\circ} \mathrm{C}$ due to the beginning of weight loss of volatile material [24-29] in the DTG evaluation profile of the samples. The first decomposition is the first degradation of biopolymer, second decomposition is the second degradation of biopolymer, and third decomposition is attributed to the third degradation of biopolymer.

The first peak of biopolymer decomposition temperature correlates with the hard segment while the second peak correlates with the degradation of the soft segment. Qualitative characterization of the degradation process is 
TABLE 1: Thermal property of BF and CB samples.

\begin{tabular}{lcc}
\hline Samples & BF & $\mathrm{CB}$ \\
\hline First decomposition $\left({ }^{\circ} \mathrm{C}\right)$ & 238 & 253 \\
$T_{\text {on }}\left({ }^{\circ} \mathrm{C}\right)$ & 94 & 126 \\
$T_{\max }\left({ }^{\circ} \mathrm{C}\right)$ & 283 & 384 \\
Weight loss $(\%)$ & $20 \%$ & $20 \%$ \\
\hline Second decomposition $\left({ }^{\circ} \mathrm{C}\right)$ & 419 & 410 \\
$T_{\text {on }}\left({ }^{\circ} \mathrm{C}\right)$ & 283 & 384 \\
$T_{\max }\left({ }^{\circ} \mathrm{C}\right)$ & 494 & 507 \\
Weight loss $(\%)$ & $57 \%$ & $53 \%$ \\
\hline$T_{\text {Third decomposition }\left({ }^{\circ} \mathrm{C}\right)}$ & 567 & 584 \\
$T_{\text {on }}\left({ }^{\circ} \mathrm{C}\right)$ & 494 & 508 \\
$T_{\max }\left({ }^{\circ} \mathrm{C}\right)$ & 678 & 679 \\
Weight loss $(\%)$ & $17 \%$ & $25 \%$ \\
\hline
\end{tabular}

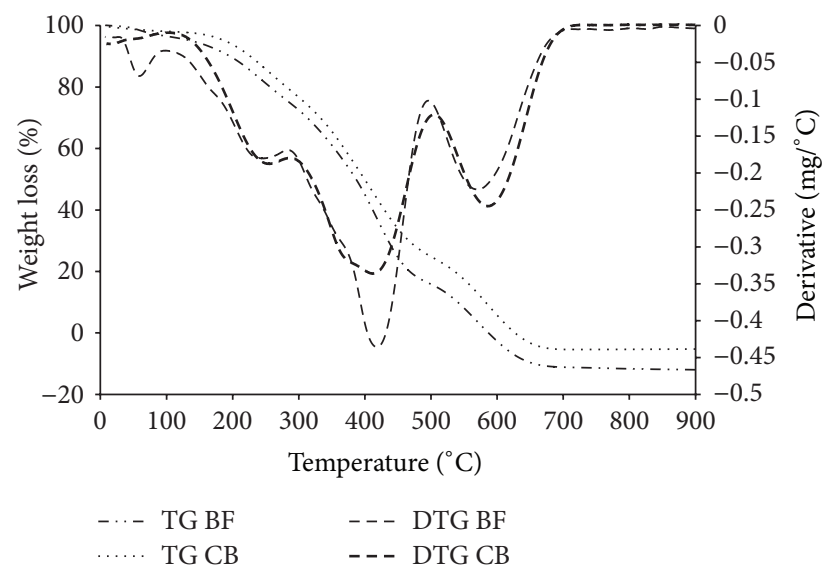

FIGURE 1: Thermogram (TG) and derivative weight loss (DTG) of BF and $\mathrm{CB}$ samples.

elaborated by the onset and maximum peak temperature of the first step $T_{1 \text { on }}$ and $T_{1 \max }$ along with the same thing for the second step $T_{2}$ and $T_{2 \max }$. The details of TGA onset decomposition temperature $\left(T_{\text {onset }}\right)$ and the maximum decomposition temperature $\left(T_{\max }\right)$ for $\mathrm{BF}$ and $\mathrm{CB}$ samples are shown in Table 1 . The onset degradation temperature $T_{\text {onset }}$ and the maximum degradation rate temperature $T_{1 \max }$ of the first $\mathrm{BF}$ degradation stage are $238^{\circ} \mathrm{C}$ and $419^{\circ} \mathrm{C}$. Figure 1 shows that the derivative weight loss of $\mathrm{BF}$ and $\mathrm{CB}$ was more than $94 \%$ and $98 \%$, respectively. The weight loss of BF was started at less than $100^{\circ} \mathrm{C}$ indicated as volatile matter in samples which is equivalent to $4.3 \%$. The hot compression moulding of $\mathrm{CB}$ samples at $90^{\circ} \mathrm{C}$ successfully removed the volatile matter. Therefore, the setting temperature of hot compression moulding was selected as $90^{\circ} \mathrm{C}$.

The decomposition temperature is attributed to the crosslinker of flexible isocyanate content. It has been suggested that the amount of weight loss at each degradation stage may be used as a quantitative measurement of the hard and soft content in biopolymer. This is indicated by the first

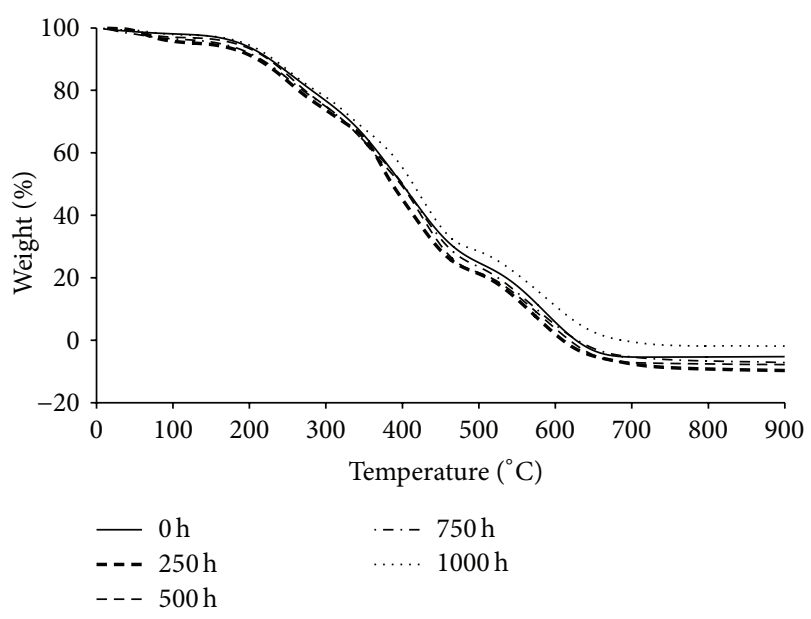

FIGURE 2: Thermogram weight loss of CB samples with UV irradiation.

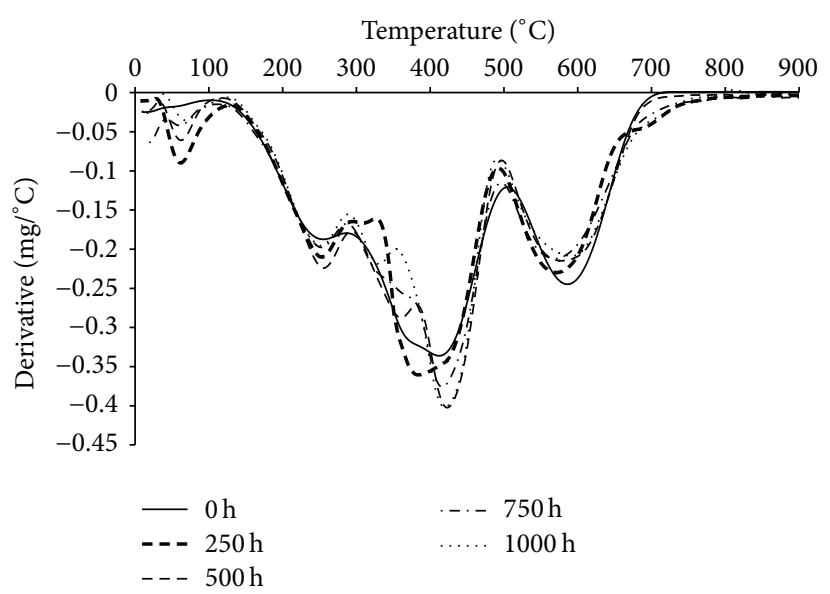

FIGURE 3: Thermogram DTG of CB samples with UV irradiation.

weight loss of $\mathrm{BF}$ and $\mathrm{CB}$ at almost the same situation for the first decomposition temperature at $238^{\circ} \mathrm{C}$ and $253^{\circ} \mathrm{C}$, and the second decomposition temperature is at $419^{\circ} \mathrm{C}$ and $410^{\circ} \mathrm{C}$, respectively.

Figures 2 and 3 show the major decomposition of $\mathrm{CB}$ samples with UV irradiation exposure in the high temperature ranges of $290^{\circ} \mathrm{C}$ to $510^{\circ} \mathrm{C}$. This peak was attributed to hard segment of crosslinker as consequence of the relatively low thermal stability of the urethane groups. The degradation of CB samples depended on thermal stability of isocyanate (crosslinker) content in which it is less thermally stable after being UV irradiated. This is indicated by the decrease of the first weight loss of CB samples at 0 hour and 250 hours of UV irradiation for the first decomposition temperature at $253^{\circ} \mathrm{C}$ and $248^{\circ} \mathrm{C}$. The second decomposition temperature is at $411^{\circ} \mathrm{C}$ and $380^{\circ} \mathrm{C}$ and the third decomposition temperature is at $584^{\circ} \mathrm{C}$ and $564^{\circ} \mathrm{C}$, respectively. The duration of CB samples UV irradiation also affected the percentages of weight loss significantly. It indicated that irradiation of $\mathrm{CB}$ samples 
TABLE 2: Thermal property of CB samples with UV irradiation exposure.

\begin{tabular}{lccccc}
\hline \multirow{2}{*}{ CB samples } & \multicolumn{5}{c}{ UV irradiation } \\
& $0 \mathrm{~h}$ & $250 \mathrm{~h}$ & $500 \mathrm{~h}$ & $750 \mathrm{~h}$ & $1000 \mathrm{~h}$ \\
\hline Volatile $\left({ }^{\circ} \mathrm{C}\right)$ & & 68 & 56 & 60 & 60 \\
$T_{\text {on }}\left({ }^{\circ} \mathrm{C}\right)$ & & 36 & 28 & 32 & 30 \\
$T_{\max }\left({ }^{\circ} \mathrm{C}\right)$ & & 180 & 184 & 164 & 184 \\
Weight loss $(\%)$ & & 5 & 2 & 3 & 2 \\
First decomposition $\left({ }^{\circ} \mathrm{C}\right)$ & 253 & 248 & 184 & 248 & 252 \\
$T_{\text {on }}\left({ }^{\circ} \mathrm{C}\right)$ & 126 & 180 & 332 & 164 & 184 \\
$T_{\max }\left({ }^{\circ} \mathrm{C}\right)$ & 384 & 312 & 492 & 280 & 284 \\
Weight loss $(\%)$ & 20 & 22 & 24 & 22 & 18 \\
Second decomposition $\left({ }^{\circ} \mathrm{C}\right)$ & 411 & 380 & 420 & 416 & 420 \\
$T_{\text {on }}\left({ }^{\circ} \mathrm{C}\right)$ & 384 & 312 & 332 & 280 & 284 \\
$T_{\max }\left({ }^{\circ} \mathrm{C}\right)$ & 508 & 460 & 492 & 494 & 484 \\
Weight loss $(\%)$ & 53 & 48 & 44 & 52 & 52 \\
Third decomposition $\left({ }^{\circ} \mathrm{C}\right)$ & 584 & 564 & 576 & 572 & 588 \\
$T_{\text {on }}\left({ }^{\circ} \mathrm{C}\right)$ & 508 & 460 & 492 & 494 & 484 \\
$T_{\max }\left({ }^{\circ} \mathrm{C}\right)$ & 679 & 660 & 650 & 650 & 668 \\
Weight loss (\%) & 25 & 25 & 23 & 23 & 28 \\
\hline
\end{tabular}

occurs due to photodegradation of biopolymer from the exposed CB samples surface.

Table 2 summarizes the percentages of derivative weight loss and decomposition temperature of $\mathrm{CB}$ samples with $\mathrm{UV}$ irradiation exposure from 0 hour to 1000 hours. The $\mathrm{CB}$ samples show that the new existing volatile peak less than $100^{\circ} \mathrm{C}$ is started with 250 hours of UV irradiation exposure. This is due to the formation of water soluble product in addition to volatile product at surface of $\mathrm{CB}$ samples during exposure to UV irradiation. The weight loss of volatile material gives $5 \%$ at 250 hours and leads to reduction of $2 \%$ at 1000 hours. The first peak of degradation of CB samples with UV irradiation was started at around $120^{\circ} \mathrm{C}$ to $290^{\circ} \mathrm{C}$, and it is attributed to the first decomposition of biopolymer. However, the second decomposition was started from $290^{\circ} \mathrm{C}$ to $510^{\circ} \mathrm{C}$ due to the degradation of polymeric hard segment phase. Meanwhile, the third decomposition stage began at $510^{\circ} \mathrm{C}$ to $670^{\circ} \mathrm{C}$ which refers to the soft segment of polymeric degradation temperature.

3.2. Kinetic Analysis (Activation Energy). The degradation process of $\mathrm{BF}$ and $\mathrm{CB}$ samples can be characterized by activation energy, measured with TGA experimental data using analytical method proposed by Flynn. This is due to mechanism changes during the degradation of biopolymer; activation energy not only is a function of chemical structure of polymer but also varies with conversion. It provides a parameter for the assessment of thermal stability of biopolymer.

Flynn method is applied to low conversion between $1 \%$ and $5 \%$ of nonisothermal differential weight loss (DTGA) method with constant heating rate, Hr. In this study, the conversion rate $\alpha$ is defined as the degree of conversion $(\alpha)$

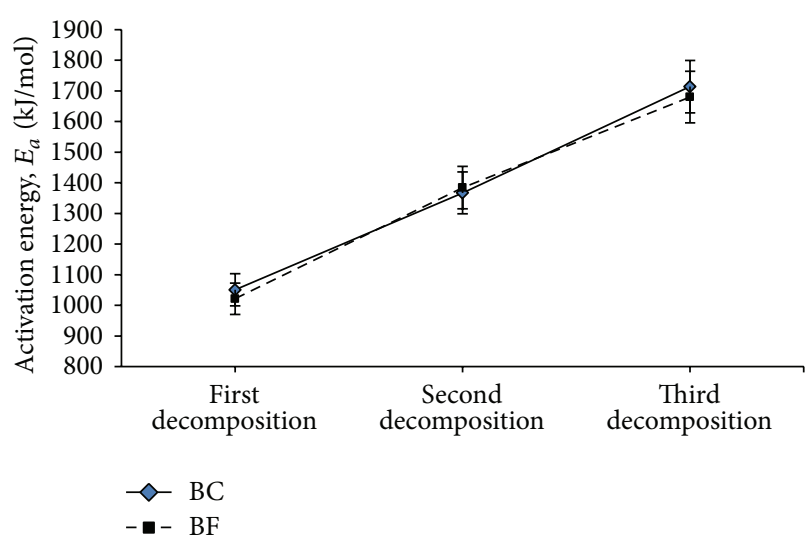

FIGURE 4: Activation energy of $\mathrm{BF}$ and $\mathrm{CB}$ samples before UV irradiation.

$=$ weight loss at the given temperature (total weight loss of the degradation), respectively [23]. $\alpha$ is defined by

$$
\alpha=1-\frac{w(t)}{w_{o}},
$$

where $w_{o}=$ initial weight, $w(t)=$ weight at any time, and $t=$ during degradation.

The fundamental rate equation in all kinetic studies is expressed as

$$
\frac{d \alpha}{d t}=k(T) f(\alpha)=A \exp \left(\frac{-E_{a}}{R T}\right) f \alpha,
$$

where $k=$ rate constant and $f(\alpha)=$ reaction model, a function depending on the actual reaction mechanism.

For nonisothermal thermogravimetric analysis at constant heating rate, (3) may be written as (4) by using Flynn method [23]

$$
\frac{d}{d t}\left\lfloor T^{2} \frac{d \alpha}{d T}\right\rfloor=\frac{E_{a}}{T}+2 T,
$$

where $E_{a}=$ activation energy $(\mathrm{kJ} / \mathrm{mol}), R=$ gas constant $(8.314 \mathrm{~J} / \mathrm{K} \cdot \mathrm{mol})$, and $T=$ absolute temperature $(\mathrm{K})$.

In this study, it is assumed that $\mathrm{BF}$ and $\mathrm{CB}$ samples are a first order reaction. Although it is not always the case, but the simplicity and the number of parameters of the first order model allow the direct comparison of different sample to provide preliminary parameter for further and more accurate modeling. In Flynn method, $T^{2}(d \alpha / d t)$ is plotted against $\alpha$ for series of experiment performed using TGA at $10^{\circ} \mathrm{C} / \mathrm{min}$ heating rate with peak temperature obtained from the DTG curve.

The activation energy of $\mathrm{BF}$ and $\mathrm{CB}$ samples is referred to in Figure 4. The activation energy of $\mathrm{BC}$ sample gives high values as compared to $\mathrm{BF}$ samples that are $1051 \mathrm{~kJ} / \mathrm{mol}$ and $1022 \mathrm{~kJ} / \mathrm{mol}$, respectively. The similar trend was observed in the third decomposition of BC samples which is $1714 \mathrm{~kJ} / \mathrm{mol}$ and $1680 \mathrm{~kJ} / \mathrm{mol}$, respectively. Furthermore, the activation energy of BF samples is the highest at the second decomposition which is $1384 \mathrm{~kJ} / \mathrm{mol}$ as compared to that of $\mathrm{BC}$ 


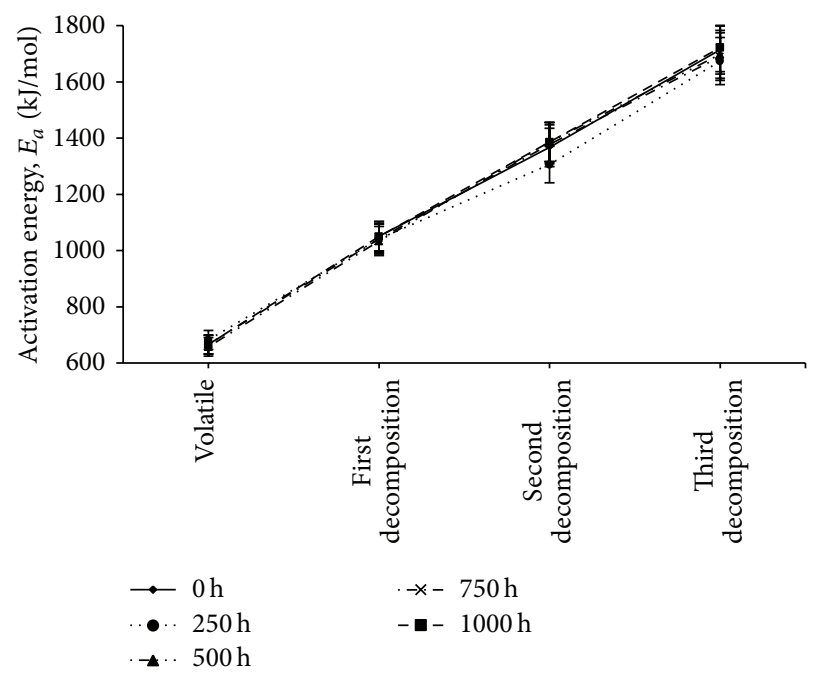

FIGURE 5: Activation energy of CB samples of UV irradiation.

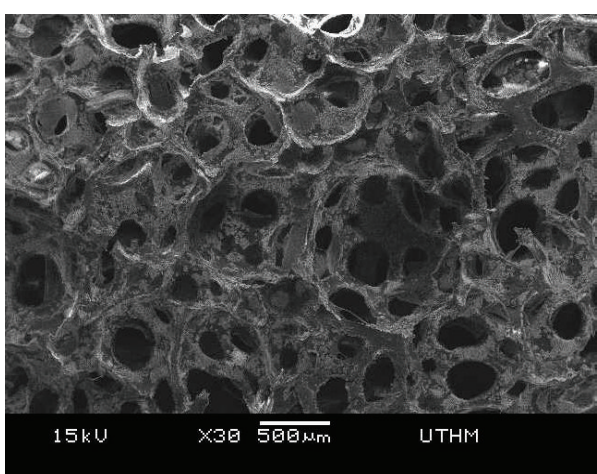

(a)

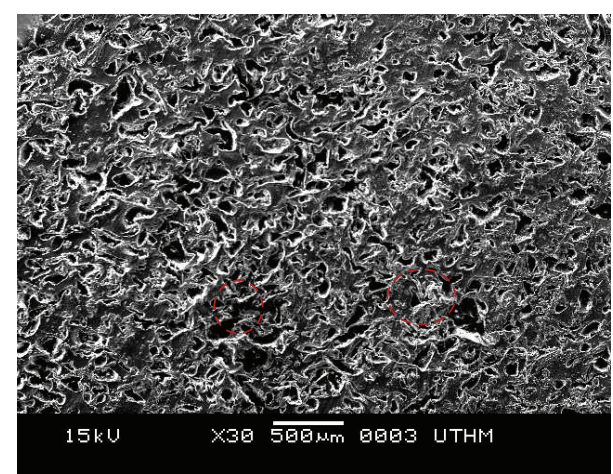

(b)

FIGURE 6: SEM micrograph: (a) BF samples (b) CB samples.

samples which is $1367 \mathrm{~kJ} / \mathrm{mol}$. This is due to the degradation of crosslinker at the hard segment in biopolymer.

Figure 5 shows the activation energy of CB samples of UV irradiation exposure from 0 hours to 1000 hours. The activation energy of $\mathrm{CB}$ samples gives similar trend on the following ranges: the first decomposition temperature (1030-1050 kJ/mol), second decomposition temperature $(1300-1390 \mathrm{~kJ} / \mathrm{mol})$, and third decomposition temperature $(1670-1725 \mathrm{~kJ} / \mathrm{mol})$, respectively. This is due to the thermal stability of $\mathrm{CB}$ samples at the hard segment that has a great influence on the thermal stability of soft segment. The higher thermal stability of hard segment leads to a higher degradation temperature of soft segment whilst the activation energy of $\mathrm{CB}$ samples is the highest at the higher thermal stability of CB samples.

In comparison, the activation energy of $\mathrm{CB}$ samples of $\mathrm{UV}$ irradiation at the volatile matter which is less than $100^{\circ} \mathrm{C}$ due to evaluation of volatile matter in CB samples is the minimum activation energy of UV irradiation. As an energy barrier, activation energy provides the information of critical energy needed to start the reaction, to ensure the lower activation energy and the lowest temperature required for photostability of CB samples.

3.3. Morphology Structure. The BF samples represent having open-cell cellular structure and anisotropic. According to Gibson and Ashby (1997), it was reported that almost all manmade foams are anisotropic [30]. The open-cell structure comprises many small open windows located on the cell wall and these cause the struts formed in between the open window. The SEM results present the cell distribution of BF samples that shows uniform pore distribution, smaller cell size, and homogeneity. The larger cells were found on $\mathrm{BF}$ sample with $4.14 \mu \mathrm{m}$ compared to cellular structure of $\mathrm{CB}$ samples of $143.71 \mu \mathrm{m}$ as refer to Figure 6.

Table 3 shows the pore density per volume of $\mathrm{CB}$ and $\mathrm{BF}$ samples in which the highest is $5.59 \times 10^{6} \mathrm{~cm}^{-1}$ and the lowest is $1.56 \times 10^{6} \mathrm{~cm}^{-1}$ respectively before UV exposure. The $N v$ 
TABLE 3: Number, diameter, and pore density per volume of BF and CB samples.

\begin{tabular}{lcc}
\hline Sample & BF & CB \\
\hline Number of pores & 15 & 35 \\
Diameter of pore $(\mu \mathrm{m})$ & 411 & 104 \\
$N v\left(10^{6}\right) \mathrm{cm}^{-1}$ & 1.56 & 5.59 \\
\hline
\end{tabular}

was decreased during UV exposure down to $27.786 \times 10^{6} \mathrm{~cm}^{-1}$ of BF samples. In addition, UV irradiation exposure changed the diameter of pores size of BF samples. The pore density of BF samples was obtained by Kumar and Suh method [31]. In this method, the number of pores was examined by counting the pore in the SEM micrographs. The magnification is $M$, area of SEM image is $A$, and $\left(n \cdot M^{2} / A\right)$ would give a pore density per unit area and can be converted to pore density per volume, $N v$ as follows:

$$
N v=\left(\frac{n \cdot M^{2}}{A}\right)^{3 / 2} .
$$

Goren et al. (2010) investigated the pore density of foam provided by (5) based on the final foamed volume and not based on the initial volume of the sample influenced by filler sizes and filler surface [32].

The morphology structure of $\mathrm{CB}$ is the decrease of cell number after the tension is applied by compression technique. The spherical shapes structure of foam change to small particles and become thicker. This is due to the fact that the open-cell cellular foam is of molecular changes and is close to each other. However, the strut and cell of wall are connected to each other and elimination of cell distribution occurs. This causes the particle or cell size of CB samples to be significantly compact after using hot compression technique. This is due to the particles of the samples after being compressed.

Figure 7 shows that the morphology of the surface and cross section of CB samples were exposed to UV irradiation. The morphology of cross section structure of $\mathrm{CB}$ samples shows apparent small cell size distribution at the highest UV irradiation time exposure. The diameter cell size of $\mathrm{CB}$ samples was smaller with the increase of UV irradiation time exposure. The surface of CB samples became much rougher after UV irradiation for 1000 hours. This is caused by UV irradiation influence on the surface roughness of CB samples and photodegradation is occurring during irradiation. From the observation, the overall structure has no major difference after UV irradiation exposure, indicating that it has high photostability [21].

3.4. Density. Density is an important parameter in conjunction with the application of lightweight materials. $\mathrm{CB}$ density is higher than BF density which are $0.0561 \mathrm{~g} / \mathrm{cm}^{3}$ and $0.7838 \mathrm{~g} / \mathrm{cm}^{3}$, respectively, due to the porosity structure or particle structure of both biopolymer samples. The porosity of $\mathrm{BF}$ is higher as compared to $\mathrm{CB}$ due to the high porosity in the samples: 0.014 and 0.0043 , respectively. This is due to the fact that the materials produced from particle structure gave higher density than the materials produced from cellular structure [18].

$\mathrm{UV}$ irradiation and different percentages of $\mathrm{TiO}_{2}$ loading influence the density of samples as it is referred to in Figure 8. The density of $\mathrm{CBC}$ samples was significantly increased with the increment of $\mathrm{TiO}_{2}$ loading and fluctuated with UV irradiation up to 1000 hours. Density of CBC samples was decreased at 250 hours of UV irradiation exposure and increased slowly up to 750 hours and drop at 1000 hours. The highest density of $\mathrm{CBC}$ samples is $10 \% \mathrm{TiO}_{2}$ loading of $1.1088 \mathrm{~g} / \mathrm{cm}^{3}$ due to the amount of filler loading in the samples. However, the density of $\mathrm{CBC}$ samples was linearly increased at $7.5 \%$ of $\mathrm{TiO}_{2}$ loading from 0 hours to 750 hours and dropped at $1.091 \mathrm{~g} / \mathrm{cm}^{3}$ after 1000 hours of UV irradiation.

In general, the decrease of the density was influenced by the increase of the cell size and window cell of the foam [33]. According to the American National Standard Particleboard (1999), the material produced from particle structure gave higher density than the material produced from cellular structure [34].

3.5. Vibration Transmissibility and Damping Characteristic of $C B C$ Samples. Vibration transmissibility and damping characteristic of CBC samples significantly changed after UV irradiated exposure at different samples thickness: $10 \mathrm{~mm}$, $15 \mathrm{~mm}$, and $20 \mathrm{~mm}$. The maximum resonance peak for acceleration base excitation was observed at the range of $23-25 \mathrm{~Hz}$, and displacement base excitation was observed at the range of $19-23 \mathrm{~Hz}$. The resonance peak is equal to the vibration transmissibility of $\mathrm{CBC}$ samples as indicated in Figure 9. The lowest the thickness of $\mathrm{CBC}$ samples, the highest the reduction of vibration transmissibility. This is due to the stable vibration transmitted at the lowest thickness [22] for $\mathrm{CBC}$ samples, and more energy is dissipated when the density of the surface is increased. This situation occurs in relation to the resonance frequency of $\mathrm{CBC}$ block system which is due to the changes in stiffness during testing [35]. Furthermore, the resonance frequency and attenuation frequency shifted to the low frequency while increasing the thickness of the samples.

Damping of CBC samples was increased with the increment of UV irradiation exposure time for acceleration and displacement base excitation as it is referred to in Figure 10. The damping of CBC samples was significantly increased at the maximum transmissibility at the range of 15 to $25 \mathrm{~Hz}$. The samples structure with higher porosity and higher particles density can offer better damping characteristic [36]. In this case, $\mathrm{CBC}$ samples are able to dissipate the vibrations through the polymer composite of long molecule chains when the moveable top plates vibrate.

Figure 11 indicated the damping of $\mathrm{CBC}$ with different ratio of $\mathrm{TiO}_{2}$ loading of displacement base excitation at $1 \mathrm{~mm}$ and $1.5 \mathrm{~mm}$ with acceleration of $0.1 \mathrm{G}$ and $0.15 \mathrm{G}$ of $10 \mathrm{~mm}$ 
CB

samples

$0 \mathrm{~h}$

$250 \mathrm{~h}$

$500 \mathrm{~h}$

$750 \mathrm{~h}$
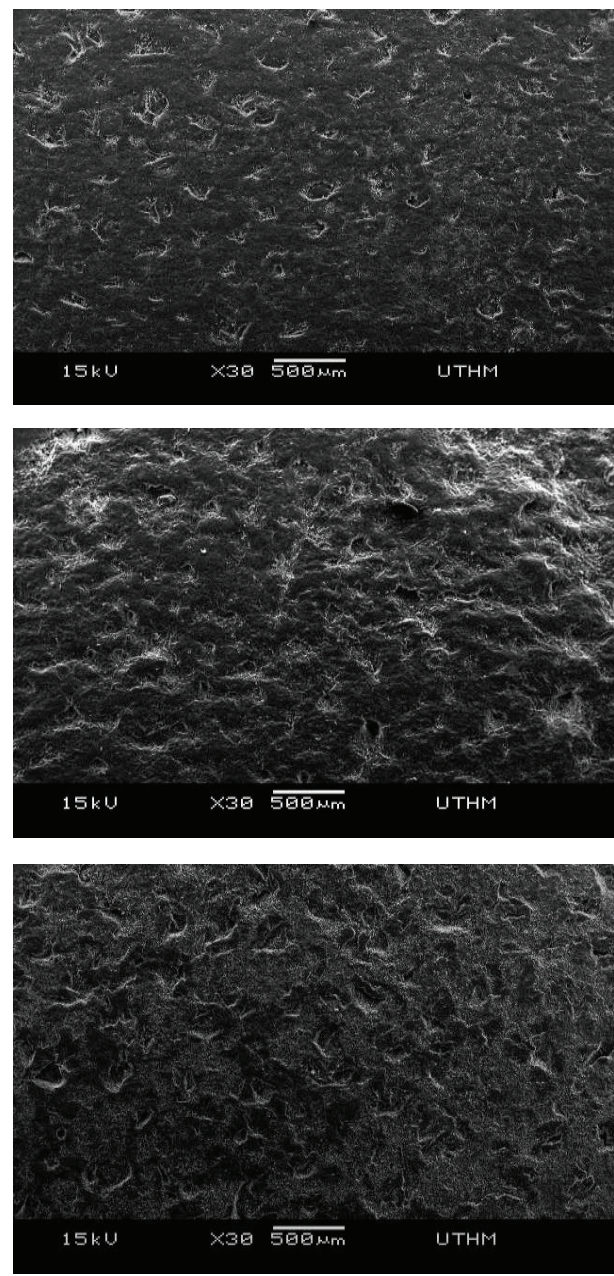

$1000 \mathrm{~h}$

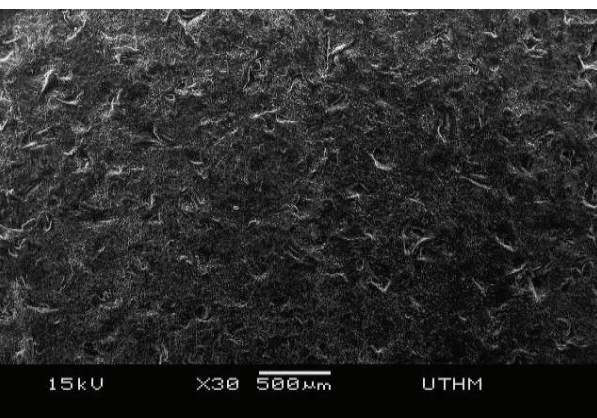

Cross section
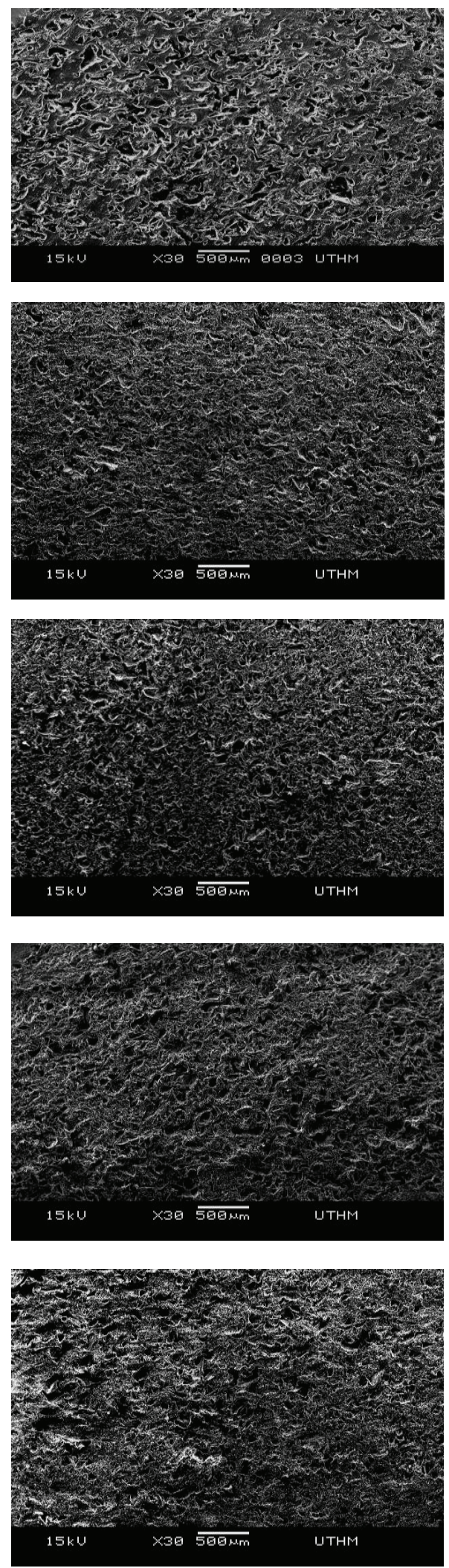

FIgURE 7: Morphology of CB samples with UV irradiation. 


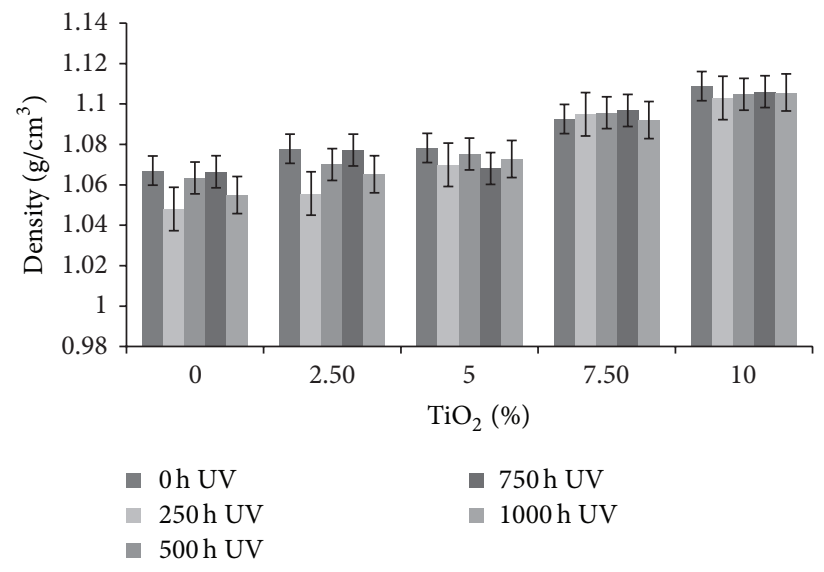

FIGURE 8: Density of CBC with different percentage loading of $\mathrm{TiO}_{2}$ and $\mathrm{UV}$ irradiation exposure.

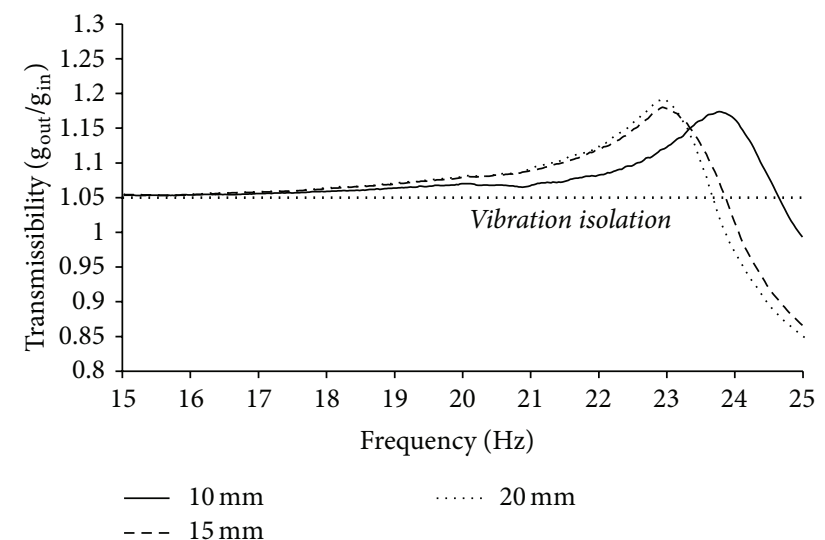

(a)

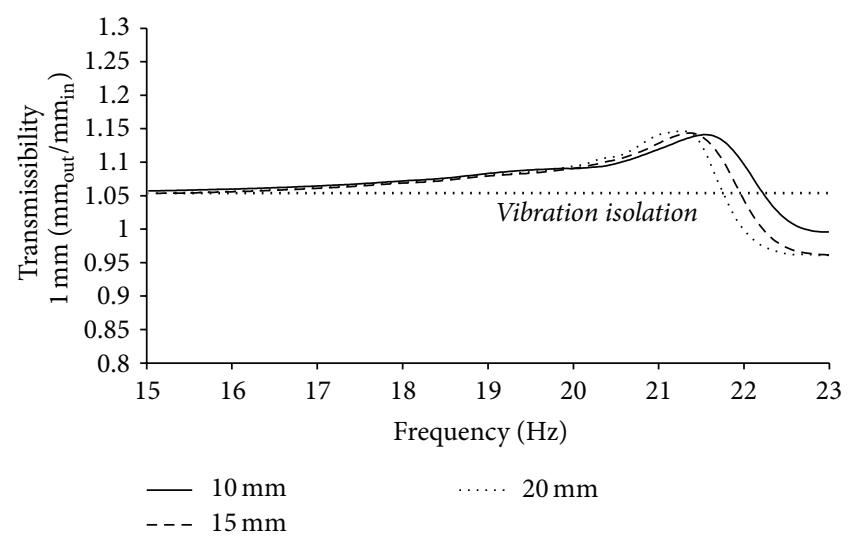

(c)

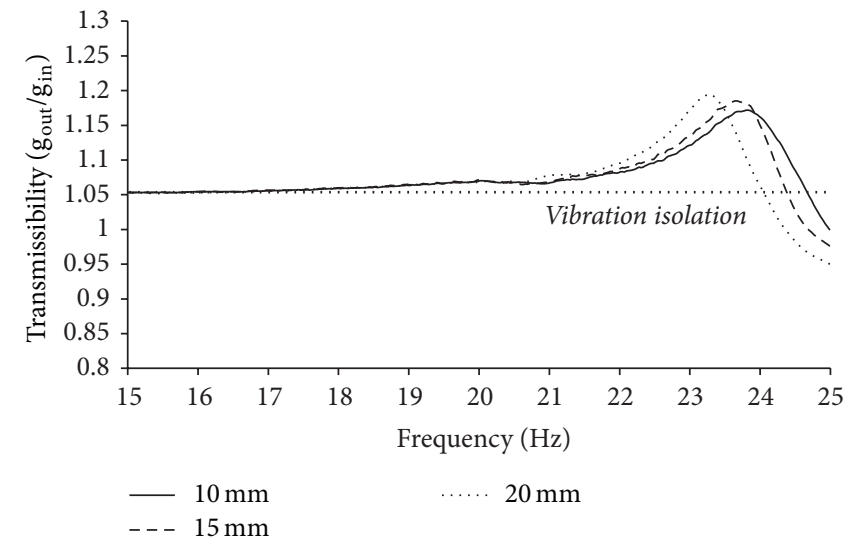

(b)

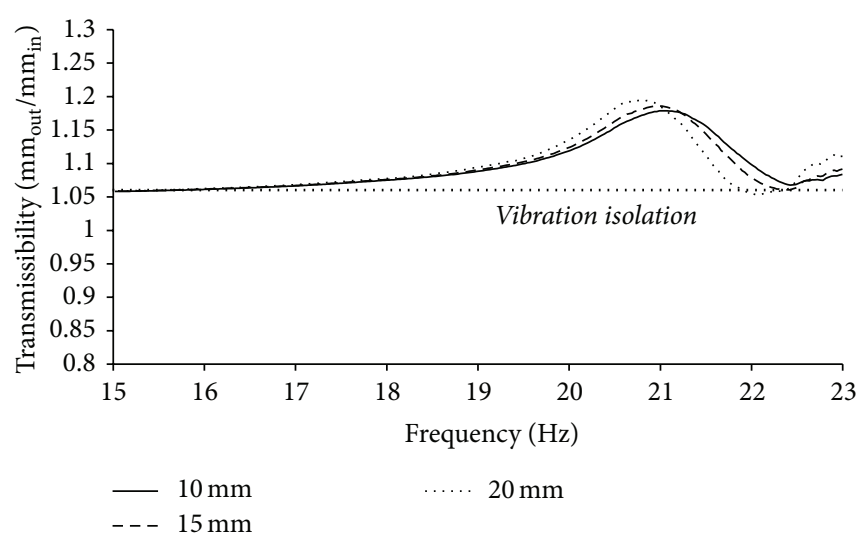

(d)

FIGURE 9: Transmissibility curve from base to moveable top plate: (a) $0.15 \mathrm{G}$ and (b) $0.1 \mathrm{G}$ and (c) $1 \mathrm{~mm}$ and (d) $1.5 \mathrm{~mm}$ base excitation. 


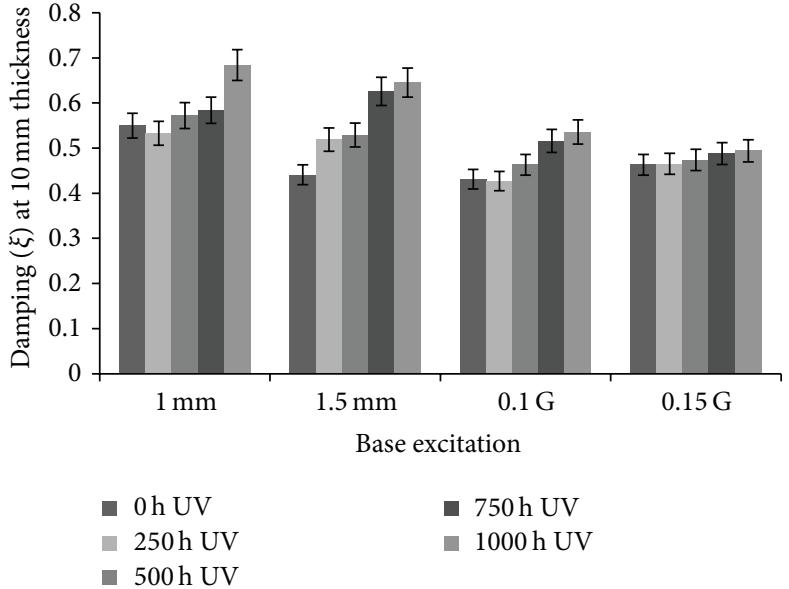

(a)

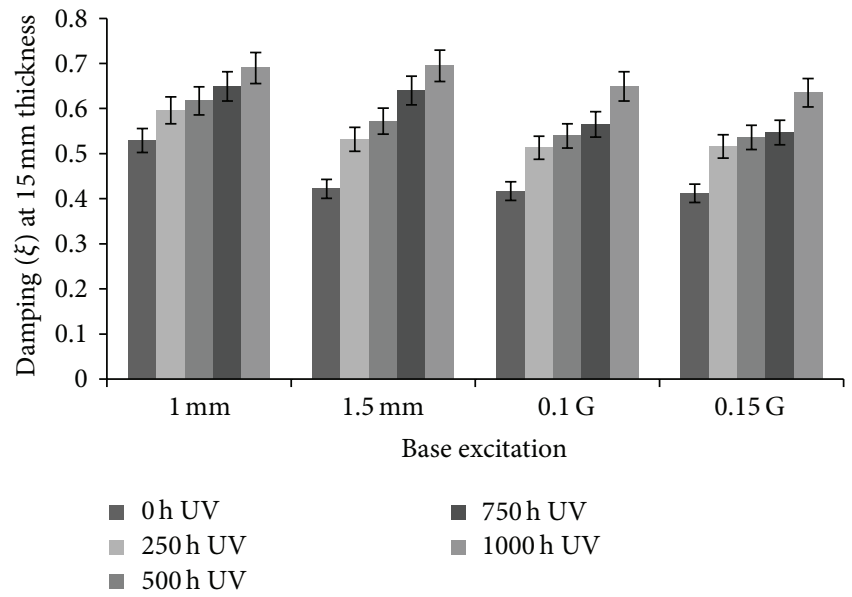

(b)

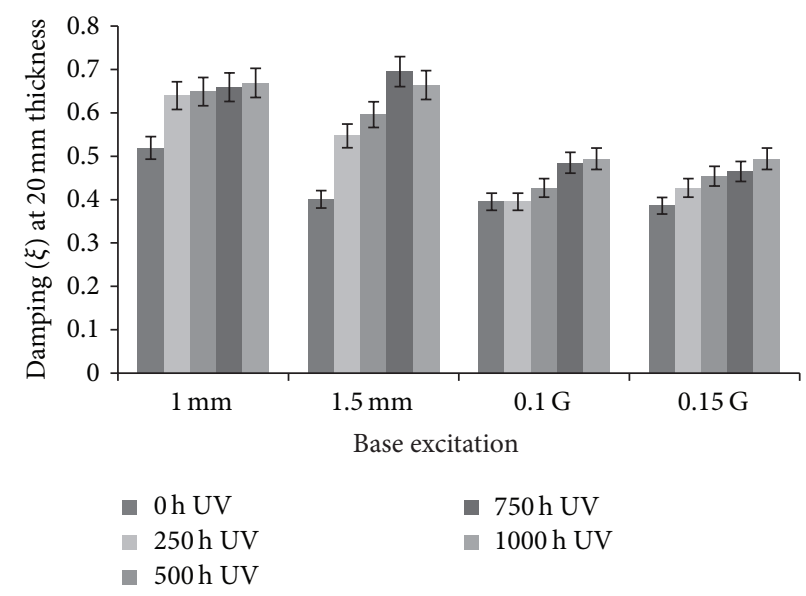

(c)

FIGURE 10: Damping of CBC samples of (a) $10 \mathrm{~mm}$, (b) $15 \mathrm{~mm}$, and (c) $20 \mathrm{~mm}$ thickness at different UV irradiation exposure time.

thickness. The results show that the damping of CBC samples is decreased with the increase of $\mathrm{TiO}_{2}$ loading. Meanwhile, in average, the increase of UV irradiation exposure times revealed that the damping characteristic of $\mathrm{CBC}$ samples was increased. These results may indicate that the molecules of CBC samples lead to the break (chain scission), crosslink, or suffering of substitution reaction after UV irradiation [37]. Therefore, this argumentation is based on the molecular motion resulting from further cross-linking leading to higher dissipation energy throughout the thermoset during the transmissibility testing.

In addition, the characteristic of damping is an important property of materials due to the fact that the damping capacity is usually used to evaluate the material ability to dissipate elastic strain energy when it is subjected to vibratory loads [38]. Hence, the damping characteristic of CBC samples has become an important requirement in the design automotive and aerospace structures [36].

\section{Conclusion}

Biopolymer flexible (BF) foam is a renewable polymer based on waste vegetable cooking oil. The thermal degradation and activation energy of $\mathrm{BF}$ and $\mathrm{CB}$ samples increase with the increasing of UV irradiation time of the first degradation, second degradation, and third degradation. The morphological structure of $\mathrm{BF}$ and $\mathrm{CB}$ samples gives smaller diameter size and increased surface roughness after UV exposure. The vibration and damping characteristic of $\mathrm{CBC}$ samples is significantly increased with the increase of UV irradiation time, the lowest thickness, and the percentages of $\mathrm{TiO}_{2}$ loading at the frequency range of $15-25 \mathrm{~Hz}$. Cross-linking influences the properties of $\mathrm{CBC}$ sample. The use of high functional reactants, for example, polyol and diisocyanate, leads to a crosslink network. Moreover, an excess of diisocyanate $(\mathrm{NCO} / \mathrm{OH})$ may cause chain branching and chemical crosslink. Thus, highly crosslink CBC is useful for application, such as insulation material or automotive part. 


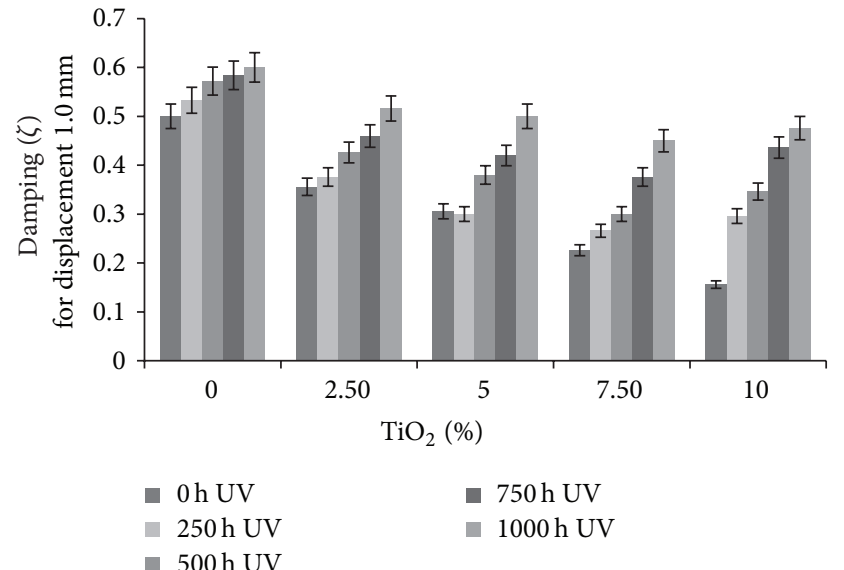

(a)

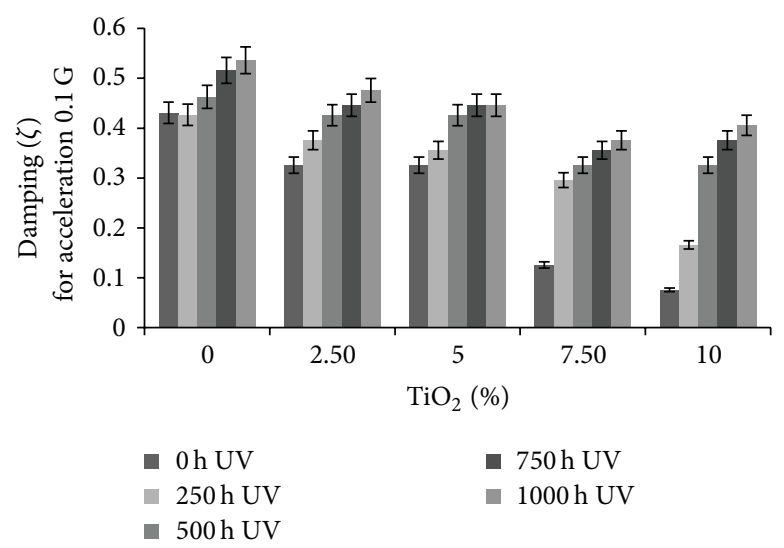

(c)

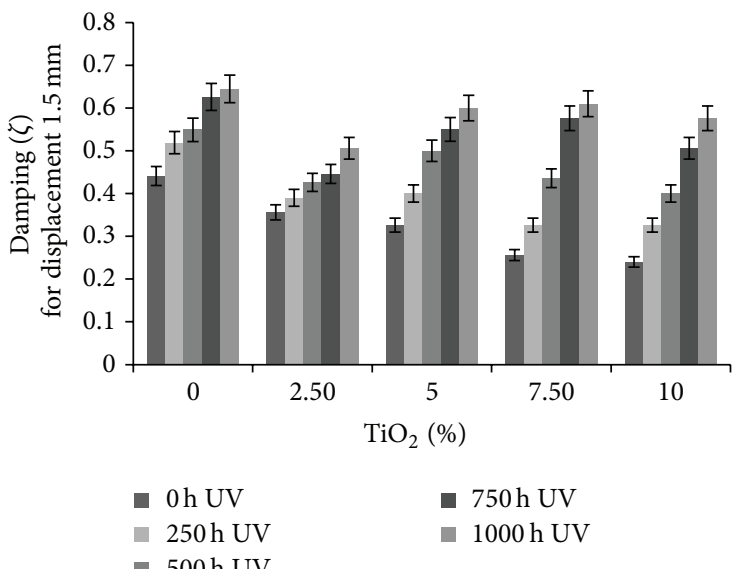

(b)

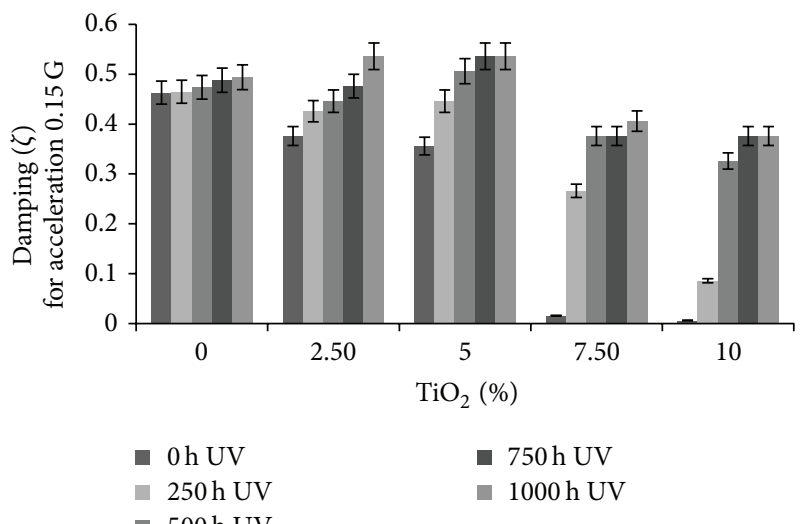

(d)

FIGURE 11: Damping of CBC samples: (a) $0.15 \mathrm{G}$ and (b) $0.1 \mathrm{G}$ and (c) $1 \mathrm{~mm}$ and (d) $1.5 \mathrm{~mm}$ base excitation of $10 \mathrm{~mm}^{\text {thickness with TiO }}{ }_{2}$ with UV irradiation.

\section{Conflict of Interests}

The authors declare that there is no conflict of interests regarding the publication of this paper.

\section{Acknowledgments}

The authors would like to thank the Malaysian Government and Universiti Tun Hussein Onn Malaysia (UTHM), Johor, and the Malaysian Technical University Centre of Excellence (MTUN CoE) for supporting this research study under research Grant Vot C014, Exploratory Researched Grant Scheme, ERGS Vot E108, and Fundamental Research Grant Scheme, FRGS Vot 1481.

\section{References}

[1] J. C. Ronda, G. Lligadas, M. Galià, and V. Cádiz, "Vegetable oils as platform chemicals for polymer synthesis," European Journal of Lipid Science and Technology, vol. 113, no. 1, pp. 46-58, 2011.

[2] S. S. Narine, X. Kong, L. Bouzidi, and P. Sporns, "Physical properties of polyurethanes produced from polyols from seed oils: II. Foams," Journal of the American Oil Chemists' Society, vol. 84 , no. 1 , pp. $65-72,2007$.
[3] A. Z. M. Rus, "Degradation studies of polyurethanes based on vegetables oils. (Part I)," Progress in Reaction Kinetics and Mechanism, Science Reviews, vol. 33, pp. 363-391, 2008.

[4] A. Z. Mohd-Rus, T. J. Kemp, and A. J. Clark, “Degradation studies of polyurethanes based on vegetable oils. Part 2. thermal degradation and materials properties," Progress in Reaction Kinetics and Mechanism, vol. 34, no. 1, pp. 1-41, 2009.

[5] N. N. M. Hassan, A. Z. M. Rus, and M. I. Ghazali, "Acoustic performance of green polymer foam from renewable resources after UV exposure," in Proceedings of the International Conference on Mechanical Engineering Research (ICMER '13), July 2013.

[6] H. Lim, S. H. Kim, and B. K. Kim, "Effects of silicon surfactant in rigid polyurethane foams," eXPRESS Polymer Letters, vol. 2, no. 3, pp. 194-200, 2008.

[7] D. Klempner and V. Sendijarevic, Polymeric Foams And Foam Technology, Hanser, Munich, Germany, 2nd edition, 2004.

[8] J. Robinson, A. Linder, A. Gemmel et al., "Comparison of standard UV test method for the ageing of cables," in Proceedings of the 60th International Wire \& Cable Symposium, pp. 329-337, 2011.

[9] A. Hazarika and T. K. Maji, "Modification of softwood by monomers and nanofillers," Defence Science Journal, vol. 64, no. 3, pp. 262-272, 2014. 
[10] R. Singh, P. Davies, and A. K. Bajaj, "Estimation of the dynamical properties of polyurethane foam through use of Prony series," Journal of Sound and Vibration, vol. 264, no. 5, pp. 10051043, 2003.

[11] G. Joshi, A. K. Bajaj, and P. Davies, "Whole-body vibratory response study using a nonlinear multi-body model of seatoccupant system with viscoelastic flexible polyurethane foam," Industrial Health, vol. 48, no. 5, pp. 663-674, 2010.

[12] J. W. Liang and B. F. Feeny, "Identifying coulomb and viscous friction from free-vibration decrements," Nonlinear Dynamics, vol. 16, no. 4, pp. 337-347, 1998.

[13] A. Z. M. Rus, "Polymers from renewable materials," Science Progress, vol. 93, no. 3, pp. 285-300, 2010.

[14] A. Z. M. Rus, "Effect of titanium dioxide on material properties for renewable rapeseed and sunflower polyurethane," International Journal of Integrated Engineering, vol. 1, no. 1, pp. 15-22, 2009.

[15] N. N. M. Hassan, A. Z. M. Rus, S. Nurulsaidatulsyida, and S. R. Mohid, "Acoustic study based on sustainable green polymer treated with $\mathrm{H}_{2} \mathrm{O}$," Advanced Materials Research, vol. 748, pp. 281-285, 2013.

[16] N. Sulong, Utilization of low hydroxyl content of waste oil polymer foam doped with waste materials for sound absorption application [M.S. thesis], Universiti Tun Hussein Onn Malaysia, 2011.

[17] A. Z. M. Rus, N. M. H. Nik, and R. A. B. Rahim, "Influence of multilayer textile biopolymer foam doped with titanium dioxide for sound absorption materials," Key Engineering Materials, vol. 594-595, pp. 750-754, 2014.

[18] N. A. Latif, A. Z. M. Rus, and A. G. M. K. Zaimy, "Effect of thickness for sound absorption of high density biopolymer foams," Key Engineering Materials, vol. 594-595, pp. 183-187, 2014.

[19] N. A. Latif, A. Z. M. Rus, and M. K. Z. A. Ghani, "Influence of hot compression moulding of particulate biopolymer and their sandwich layups for sound absorption characteristic," Applied Mechanics and Materials, vol. 465-466, pp. 1044-1048, 2014.

[20] S. M. Rus, N. A. Latif, M. I. Ghazali, and A. Z. M. Rus, "Characteristics of UV irradiated waste biopolymer from renewable resources (Part 1)," Advanced Materials Research, vol. 974, pp. 252-256, 2014.

[21] S. M. Rus, M. I. Ghazali, and A. Z. M. Rus, "Characteristics of UV irradiated waste biopolymer from renewable resources (Part 2)," Advanced Materials Research, vol. 974, pp. 257-261, 2014.

[22] N. A. Latif and A. Z. M. Rus, "Vibration transmissibility study of high density solid waste biopolymer foam," Journal of Mechanical Engineering and Sciences, vol. 6, pp. 772-781, 2014.

[23] Y. M. Song, W. C. Chen, T. L. Yu, K. Linliu, and Y. H. Tseng, "Effect of isocyanates on the crystallinity and thermal stability of polyurethanes," Journal of Applied Polymer Science, vol. 62, no. 5, pp. 827-834, 1996.

[24] J. M. Cervantes-Uc, J. V. Cauich-Rodríguez, H. Vázquez-Torres, and A. Licea-Claveríe, "TGA/FTIR study on thermal degradation of polymethacrylates containing carboxylic groups," Polymer Degradation and Stability, vol. 91, no. 12, pp. 3312-3321, 2006.

[25] S. S. Idris, N. A. Rahman, K. Ismail, A. B. Alias, Z. A. Rashid, and M. J. Aris, "Investigation on thermochemical behaviour of low rank Malaysian coal, oil palm biomass and their blends during pyrolysis via thermogravimetric analysis (TGA)," Bioresource Technology, vol. 101, no. 12, pp. 4584-4592, 2010.
[26] M. Ardanuy, M. Antunes, and J. I. Velasco, "Vegetable fibres from agricultural residues as thermo-mechanical reinforcement in recycled polypropylene-based green foams," Waste Management, vol. 32, no. 2, pp. 256-263, 2012.

[27] S. Ibrahim and M. R. Johan, "Thermolysis and conductivity studies of poly (ethylene oxide) (PEO) based polymer electrolytes doped with carbon nanotube," International Journal of Electrochemical Science, vol. 7, no. 3, pp. 2596-2615, 2012.

[28] S. Gopalakrishnan, N. T. Nevaditha, and C. V. Mythili, "Synthesis and characterization of bifunctional monomers for high performance polymers from renewable resource," International Journal of ChemTech Research, vol. 4, no. 1, pp. 48-54, 2012.

[29] R. Artiaga, S. Naya, A. García, F. Barbadillo, and L. García, "Subtracting the water effect from DSC curves by using simultaneous TGA data," Thermochimica Acta, vol. 428, no. 1-2, pp. 137-139, 2005.

[30] L. J. Gibson and M. F. Ashby, Cellular Solid: Structure and Properties, Cambridge University Press, Cambridge, UK, 2nd edition, 1997.

[31] V. Kumar and N. P. Suh, "A process for making microcellular thermoplastic parts," Polymer Engineering and Science, vol. 30, no. 20, pp. 1323-1329, 1990.

[32] K. Goren, L. Chen, L. S. Schadler, and R. Ozisik, "Influence of nanoparticle surface chemistry and size on supercritical carbon dioxide processed nanocomposite foam morphology," The Journal of Supercritical Fluids, vol. 51, no. 3, pp. 420-427, 2010.

[33] X. Mao, S. Shimai, and S. Wang, "Gelcasting of alumina foams consolidated by epoxy resin," Journal of the European Ceramic Society, vol. 28, no. 1, pp. 217-222, 2008.

[34] Composite Panel Association, American National Standard Particleboard, Premiere Court, Gaithersburg, Md, USA, 1999.

[35] H. R. Sankar, P. Krishna, V. B. Rao, and P. B. Babu, "The effect of natural rubber particle inclusions on the mechanical and damping properties of epoxy-filled glass fibre composites," Proceedings of the Institution of Mechanical Engineers, Part L: Journal of Materials: Design and Applications, vol. 224, no. 2, pp. 63-70, 2010.

[36] R. F. Gibson and I. C. Finegan, "Recent research on enhancement of damping in polymer composites," Composite Structures, vol. 44, no. 2-3, pp. 89-98, 1999.

[37] T. Xu, G. Li, and S.-S. Pang, "Effects of ultraviolet radiation on morphology and thermo-mechanical properties of shape memory polymer based syntactic foam," Composites-Part A: Applied Science and Manufacturing, vol. 42, no. 10, pp. 15251533, 2011.

[38] J. Gu, G. Wu, and Q. Zhang, "Effect of porosity on the damping properties of modified epoxy composites filled with fly ash," Scripta Materialia, vol. 57, no. 6, pp. 529-532, 2007. 

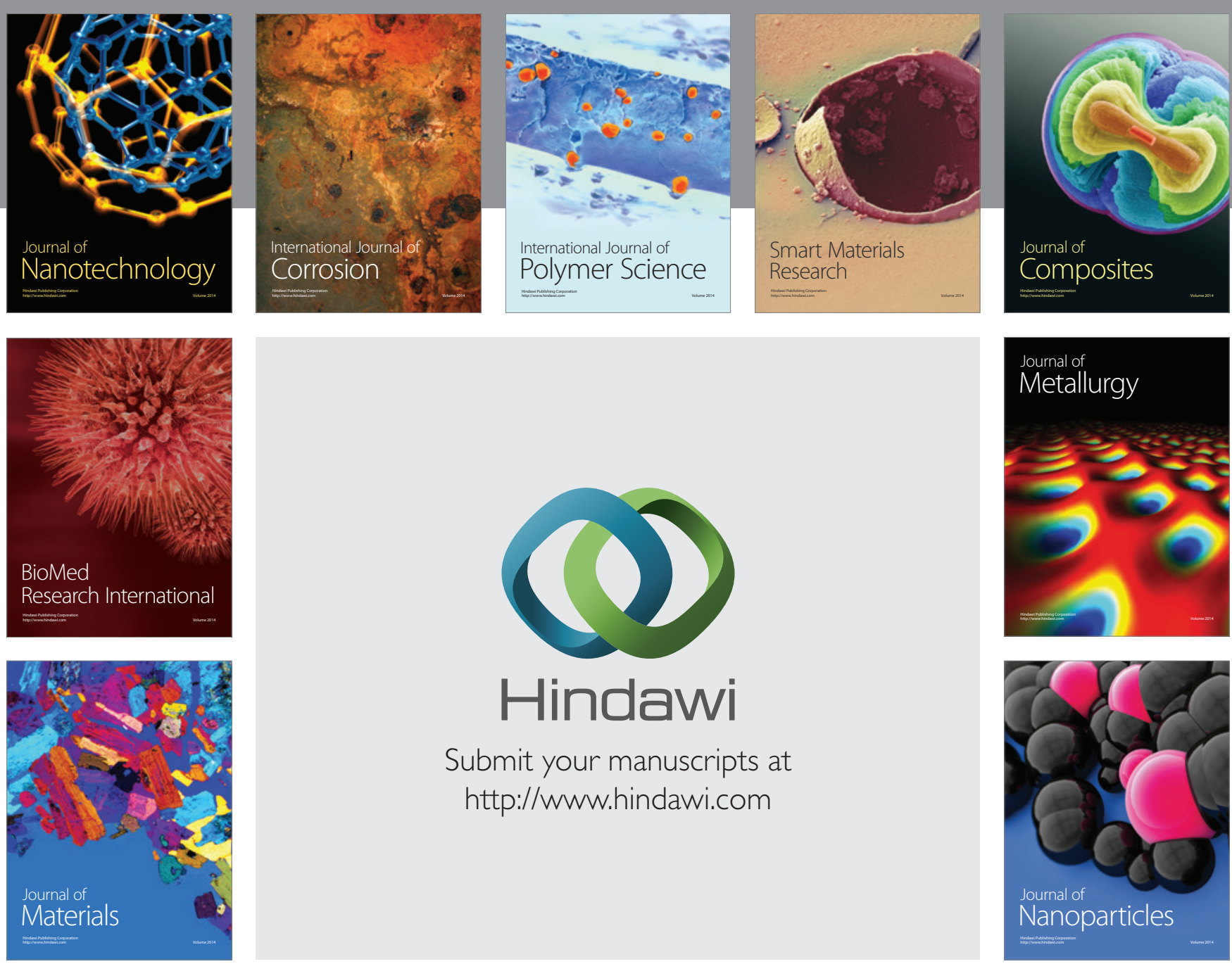

Submit your manuscripts at http://www.hindawi.com
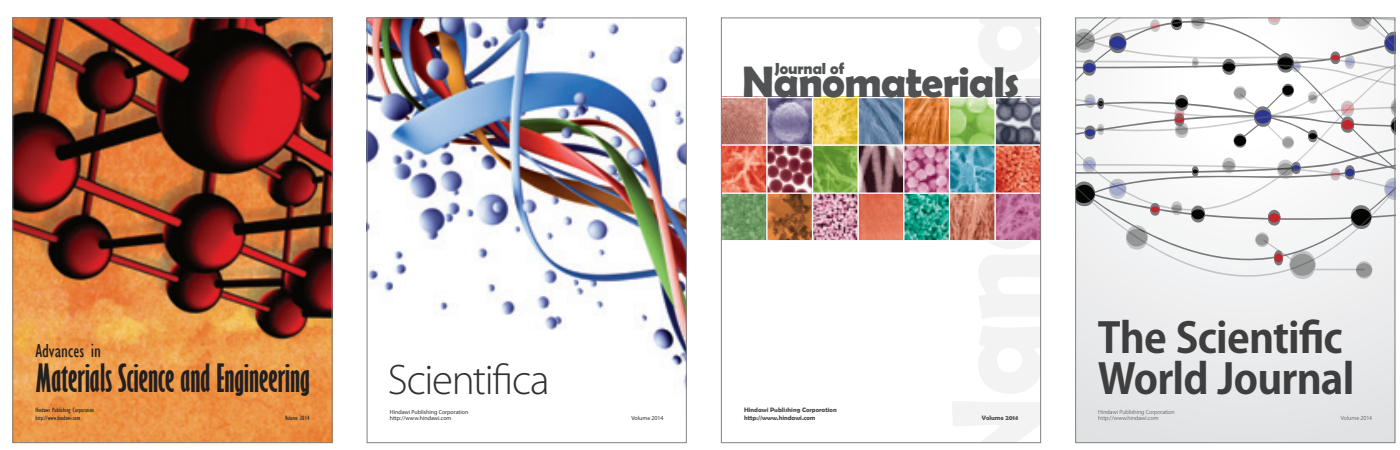

\section{The Scientific World Journal}
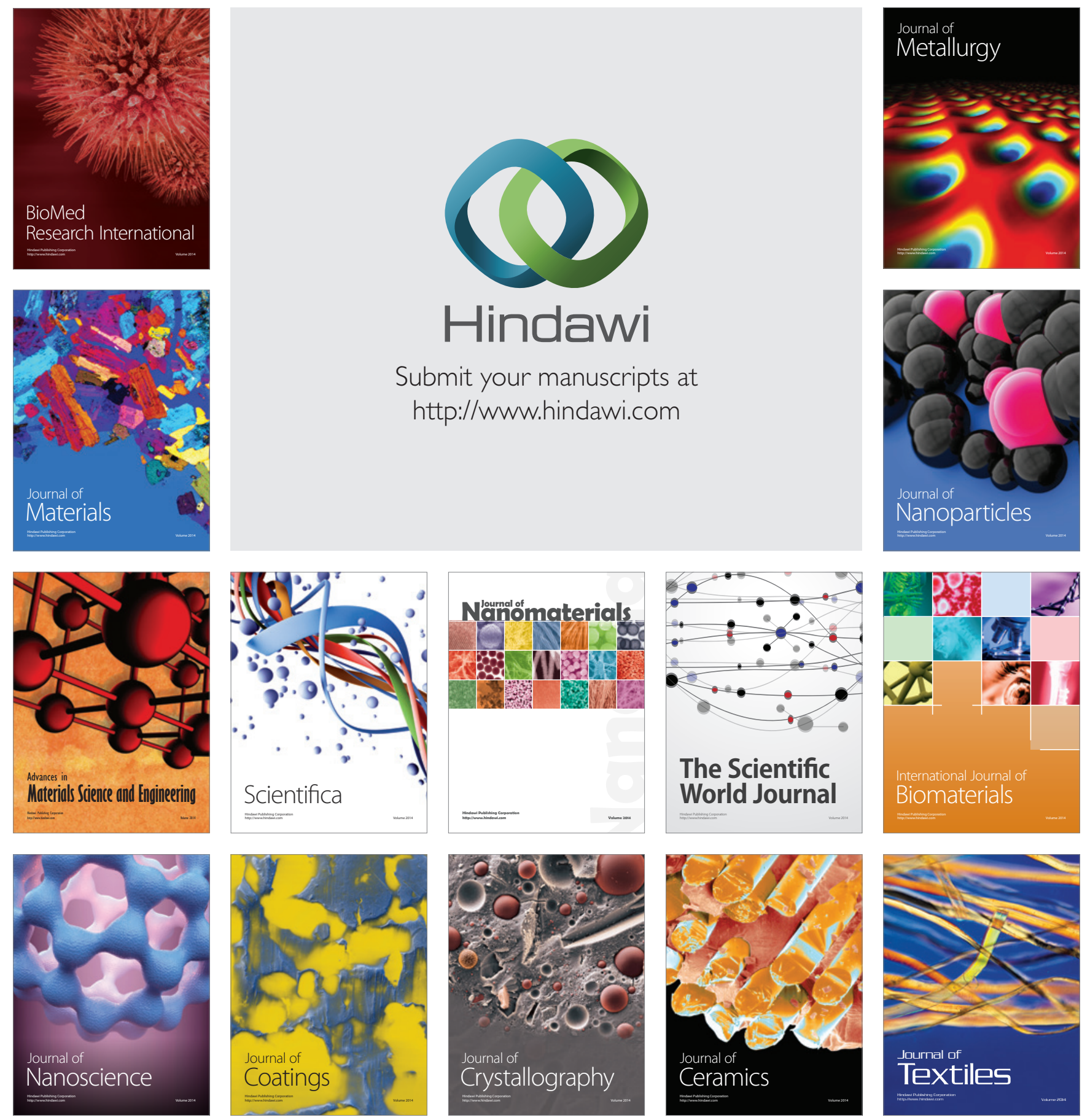